\title{
The marine algal (seaweed) flora of the Azores: additions and amendments
}

\author{
Ian Tittley ${ }^{1, *}$ and Ana I. Neto ${ }^{2}$ \\ ${ }^{1}$ Department of Botany, Natural History Museum, \\ Cromwell Road, London SW7 5BD, UK, e-mail: \\ i.tittley@nhm.ac.uk \\ ${ }^{2}$ Centro de Investigaçao dos Recursos Naturais (CIRN) \\ and Departamento de Biologia, Universidade dos \\ Açores, Rua da Mãe de Deus, 9500 Ponta Delgada, \\ Azores, Portugal \\ ${ }^{*}$ Corresponding author
}

\begin{abstract}
Thirteen species of benthic marine algae are reported new for the isolated mid-Atlantic Azores archipelago and five older records are confirmed. Seven (Bangia atropurpurea, Codium fragile spp. tomentosoides, Ectocarpus fasciculatus, E. siliculosus, Porphyrostromium ciliare, Ulothrix flacca and Ulvaria oxysperma) are widespread amphi-Atlantic species some of which extend in distributional range south to the Canary Islands. Cryptonemia seminervis, Ctenosiphonia hypnoides and Phyllophora sicula are known from the northeastern Atlantic Ocean only and also occur in the Canary Islands. The Azores archipelago is the western limit of distribution of Codium fragile ssp. atlanticum, Bostrychia scorpioides, Bryopsis cupressina, Erythroglossum laciniatum, Haliptilon squamatum and Phyllophora sicula, and the southern limit of C. fragile ssp. atlanticum and E. laciniatum. The tropical species Phyllodictyon anastomosans, Valonia macrophysa and Wurdemannia miniata reach their northern limit of distribution there. Asparagopsis taxiformis is now less common possibly due to competition with the non-native $A$. armata; subspecies of the non-native $C$. fragile now occur widely in the Azores. The status of Fucus vesiculosus, Ulva (Enteromorpha) clathrata and Rhizoclonium tortuosum is clarified and other species have been removed from the flora. The continuing addition of new species records for the Azores shows the archipelago to be floristically richer than other Atlantic islands except for the Canary Islands.
\end{abstract}

Keywords: Azores; benthic marine macroalgae; biogeography; morphology; taxonomy.

\section{Introduction}

Intensive fieldwork in the Azores at times of the year, locations and in environments not previously studied continues to add new species records of benthic marine algae to the flora of this isolated group of islands. Improved floristic knowledge for the Azores archipelago contributes to a clearer understanding of floristic rela- tionships in the North Atlantic Ocean but raises questions as to the means of species dispersal to the islands and the origin of the flora. Tittley et al. (2001) presented a review of the current status of the marine flora and since then further new species records have been reported by Parente and Neto (2000), Parente et al. (2000), Neto (2001) and Neto et al. (2002). A reappraisal of older herbarium collections, such as that of Botelho Gonçalves in the Natural History Museum, London (BM), has also contributed new species records. In this paper 13 species and two subspecies are reported new for the archipelago, and six old species records are confirmed. The status of two species involving revised nomenclature is clarified and 15 species, one of which is a rafting species, have been removed from the flora.

\section{Materials and methods}

Some of the algae referred to in this paper were collected during field studies at eulittoral and sublittoral levels on rocky shores on the island of São Miguel in late winter and early spring, periods of the year previously floristically less well investigated. Other species were identified from previous collections from other islands and from older herbarium collections in the Natural History Museum, London. Material collected during recent fieldwork was either fixed in $5 \%$ formalin seawater or was pressed and dried. When necessary material was prepared as microscope slides by staining material with aniline blue and permanently mounted using 'Karo' ${ }^{\circledR}$ corn syrup (Best Foods, Englewood Cliffs, USA). Dried specimens from previous collections were re-hydrated and prepared for microscopic examination as above. All specimens were given an individual registration number and deposited in the herbaria of the University of the Azores (UA) and BM. Nomenclature used here is taken from Algaebase (June, 2004; http://www.algaebase.org).

\section{Results}

\section{Systematic account, new species records}

Chlorophycota, Chlorophyceae, Ulvales, Ulvaceae: Ulvaria oxysperma (Kützing) Bliding Described and illustrated in Bliding (1968), pp. 585-590, figures 31-33.

Thalli formed translucent membranous tufts $10-20 \mathrm{~mm}$ high. Thalli were monostromatic with distinct basal, deeply pigmented, club-shaped rhizoidal cells (Figure 1) and attached by a small basal holdfast. Cells in middle parts of the frond measured 15-20 $\mu \mathrm{m}$ in diameter, contained a single pyrenoid and were often arranged in 
groups of two or four. Fertile material has not been observed in the Azores. These small tufted thalli grew closely adherent to rock and formed a distinct narrow band at upper eulittoral levels in early spring.

Ulvaria oxysperma occurs widely in the North Atlantic Ocean, with a southern limit in the east on the Canary Islands (Haroun et al. 2002).

Specimen examined: São Miguel, Lagoa, 18.03.2002, SMG-02-51 (UA).

\section{Cladophorales, Valoniaceae: Valonia macrophysa} Kützing Described and illustrated in Taylor (1960), pp. 110-111, plate 2 , figure 6 , plate 7 , figure 4 .

The species occurred as mats of dark-green, irregularly swollen, ovoid or cylindrical non-cellular branched vesicles, 5-15 mm in diameter and to $20 \mathrm{~mm}$ tall. Vesicles were usually crowded, adherent to the substratum and attached by rhizoids growing from small lenticular cells. Fertile material has not been observed in the Azores. Occasional patches grew on low eulittoral rocks among a turf of other algal species.

Valonia macrophysa occurs widely in the subtropical and tropical Atlantic Ocean and Mediterranean Sea but although present in the Madeiran archipelago (Neto et al. 2001) and the Canary Islands (Afonso-Carillo and Sansón 1999), is absent from West Africa (Lawson and John 1987).

Specimens examined: São Miguel, Caloura, 25.02.2003, SMG-03-11 (UA); São Miguel, Pópulo, 01.03.2002, SMG-02-42 (UA).

Bryopsidales, Bryopsidaceae: Bryopsis cupressina J.V. Lamouroux Described and illustrated in Lamouroux (1809), p. 333, and Afonso-Carillo and Sansón (1999), p. 138.

This alga occurred as small, tufted, plumose thalli that grew to $55 \mathrm{~mm}$ high. The main axis was undivided with branchlets on all sides but restricted to the upper part of the main axis. The lower branchlets were longer than the upper ones. Fertile material has not been observed in the Azores. Thalli grew in rock-pools at mid and low eulittoral levels.

Bryopsis cupressina is widespread in the Mediterranean Sea, present in the Canary Islands (Haroun et al. 2002) and to the south (Harper and Garbary 1997).

Specimens examined: São Miguel, Caloura, 25.02.2003 SMG-03-37, SMG-03-43 (UA); São Miguel, Lagoa, 17.04.2003, SMG-03-82 (UA); São Miguel, Mosteiros, 16.05.2003, SMG-03-93 (UA).

Bryopsidales, Bryopsidaceae: Codium fragile (Suringar) Hariot ssp. atlanticum (Cotton) P.C. Silva Described and illustrated in Silva (1955), p. 565, figure 1.

Thalli formed dark-green, terete, branched erect fronds to $180 \mathrm{~mm}$ tall attached by a discoid holdfast. Branching was dichotomous with non-flattened nodes. Thalli comprised aggregated siphonous filaments; the apices of the utricles were rounded, 50-290 $\mu \mathrm{m}$ in diameter with short mucrons to $7.5 \mu \mathrm{m}$ long. Fertile material has not been found in the Azores. Codium fragile ssp. atlanticum grew in rock-pools and on rocks at sublittoral levels to $15 \mathrm{~m}$ depth.

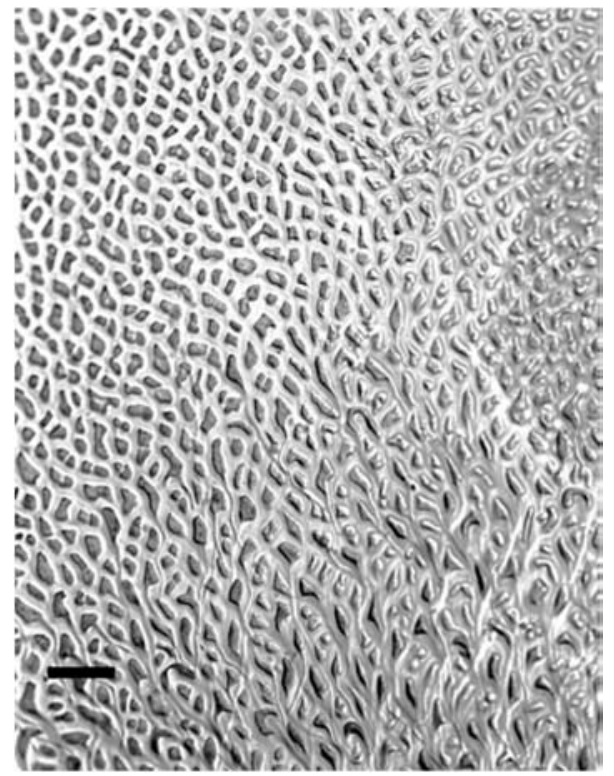

Figure 1 Ulvaria oxysperma: monostromatic thallus and rhizoidal cells near the base. Bar $=50 \mu \mathrm{m}$.

This subspecies is an introduction from the Pacific to the northeastern Atlantic Ocean (Farnham 1998).

Specimens examined: Flores, Santa Cruz, Porto Velho, 08.1994 BM000519602 (BM); Flores, Santa Cruz Bay, 19.07.1995 BM000044641, 27.07.1995 BM000044620 (BM); Flores, Santa Cruz, 05.07.1999, FLW-99-86 (UA); São Miguel, São Rocque, 27.08.1994, SMG-94-256 (UA).

Bryopsidales, Bryopsidaceae: Codium fragile ssp. tomentosoides (Goor) P.C. Silva Described and illustrated in Silva (1955), p. 567, figure 2.

Thalli were similar to Codium fragile ssp. atlanticum and grew to $220 \mathrm{~mm}$ tall but differed in having long (to $65 \mu \mathrm{m}$ ) and pointed mucrons at the apices of the utricles. Codium fragile ssp. tomentosoides grew in rock-pools and on rocks at low eulittoral and sublittoral levels to $14 \mathrm{~m}$ depth.

This subspecies is also an introduction from the Pacific Ocean (Farnham 1998) but has an amphi-Atlantic distribution.

Specimens examined: Corvo, Portinho de Area, 08.07.1999, COR-99-01 (UA); São Miguel, Ponta Delgada, 23.09.1993, SMG-93-36 (UA); São Miguel, Ponta Delgada, 25.09.1993, SMG-93-68 (UA); São Miguel, Lagoa, 25.07.1996, SMG-96-362 (UA); São Miguel, Populo, 01.04.1998, SMG-98-1654 (UA); São Miguel, Viteleiro, 08.07.2003, SMG-03-156 (UA).

\section{Chromophycota, Phaeophyceae, Ectocarpales, Ecto-} carpaceae: Ectocarpus fasciculatus Harvey Described and illustrated in Russell (1966), pp. 268-274, figures 1, 2 .

This alga occurred as erect filamentous tufts to $70 \mathrm{~mm}$ high; filaments were uniseriate, irregularly branched, constricted by the transverse walls; cells were cylindrical to $112 \mu \mathrm{m}$ long, 6 times as long as wide and contained ribbon-shaped chloroplasts. Plurilocular sporangia were 
often pedicellate on lateral branches sometimes terminal on short branches, wider in the middle parts to $133 \mu \mathrm{m}$ long and $41 \mu \mathrm{m}$ wide. Unilocular sporangia have not been found in the Azores. Ectocarpus fasciculatus grew epilithic, and epiphytic on Sargassum vulgare C. Agardh and Symphyocladia marchantioides (Harvey) Falkenberg at mid-eulittoral levels.

Ectocarpus fasciculatus is an amphi-Atlantic species that extends south to the Canary Islands (Haroun et al. 2002).

Specimens examined: Faial, Praia dos Ingleses, 19.07.1971, BM000655480 (BM); São Miguel, Calhetas, 24.05.1998, SMG-98-471 (UA); São Miguel, São Vicente, 20-03-2002, SMG-02-90 (UA); São Miguel, Capelas, 21.03.2002, SMG-02-106 (UA); São Miguel, Caloura, 25.02.2003, SMG-03-36 (UA); São Miguel, Fererria, 27.03.2004, SMG-04-60 (UA).

Rhodophycota, Bangiophycideae, Erythropeltidales, Erythropeltidaceae: Porphyrostromium ciliare (Carmichael ex Harvey in Hooker) M.J. Wynne Described and illustrated in Brodie and Irvine (2003), p. 82, figures 26, 27.

Thalli formed small filiform tufts; they were of narrow, mostly undivided, filaments with the lower part uniseriate, the middle and upper parts parenchymatous (2-4 cells wide, Figure 2), and attached by a small multicellular base (Figure 3). Cells were variable in size and shape, often rectangular, from $10 \mu \mathrm{m}$ long by $5 \mu \mathrm{m}$ wide to $10 \mu \mathrm{m}$ long by $17.5 \mu \mathrm{m}$ wide. Fertile material with monosporangia was recorded. Occasional tufts grew on Pterocladiella capillacea (S.G. Gmelin) Santelices et Hommersand and other algae at low eulittoral levels.

Porphyrostromium ciliare occurs widely in the North Atlantic Ocean south to the Canary Islands (Haroun et al. 2002), and in temperate and tropical America.

Specimens examined: São Miguel, Capelas, 21.03.2002, SMG-02-111, SMG-02-130 (UA).

Florideophycideae, Corallinales, Corallinaceae: Haliptilon squamatum (Linnaeus) Johansen, L. Irvine et Webster Described and illustrated in Irvine and Chamberlain (1994), p. 49, figure 16.

Thalli formed small, erect, tufts to $50 \mathrm{~mm}$ high, attached by a discoid base. Fronds were plumose, with an occasionally dichotomously branched main axis; lateral branches arose from an intergeniculum and branching was pinnate. Intergenicular segments measured 0.6-1 mm long and 0.6-1 mm wide. Reproductive conceptacles were formed terminally on branches.

Haliptilon squamatum occurs in the northeastern Atlantic Ocean from Britain and Ireland to the Canary Islands (Haroun et al. 2002) and possibly further south (Price et al. 1992).

Specimen examined: São Miguel, São Vicente, 08.07.1996, SMG-96-89 (UA).

Gigartinales, Phyllophoraceae: Phyllophora sicula (Kützing) Guiry et L. Irvine Described and illustrated in Dixon and Irvine (1977), p. 225, figure 82.

Thalli grew to $4 \mathrm{~cm}$ tall and comprised once or twice divided erect fronds that arose from a stipe more than

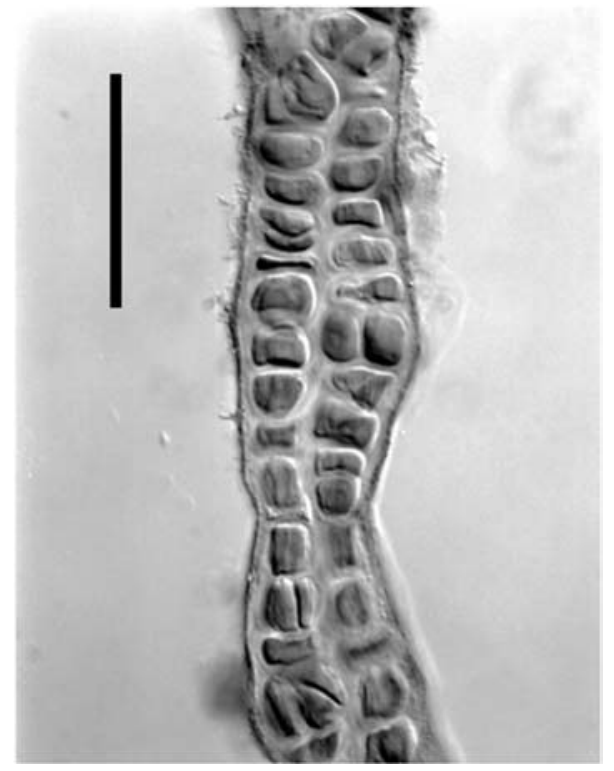

Figure 2 Porphyrostromium ciliare: cells of a filament. Bar $=50 \mu \mathrm{m}$.

$10 \mathrm{~mm}$ in length that grew from an attachment disc. Thallus multiaxial with a medulla of large cells surrounded by a cortex of 1-2 cell layers; cortical cells in surface view measured $6 \mu \mathrm{m}$ in diameter. Thalli grew at low eulittoral levels in crevices on open rock and in pools often among other algae.

Phyllophora sicula occurs in the temperate North Atlantic Ocean from mid Britain and Ireland to Morocco and the Mediterranean Sea (Dixon and Irvine 1977).

Specimens examined: São Miguel, São Vicente, 25.09.1993, SMG-93-93 (UA); São Miguel, São Vicente, 15.07.1994, SMG-94-156 (UA); São Miguel, Maia Harbour, 20.02.1998, SMG-98-68 (UA); São Miguel, Mosteiros, 07.05.1998, SMG-98-279 (UA); São Miguel, Fererria, 27.03.2004, SMG-04-49 (UA).

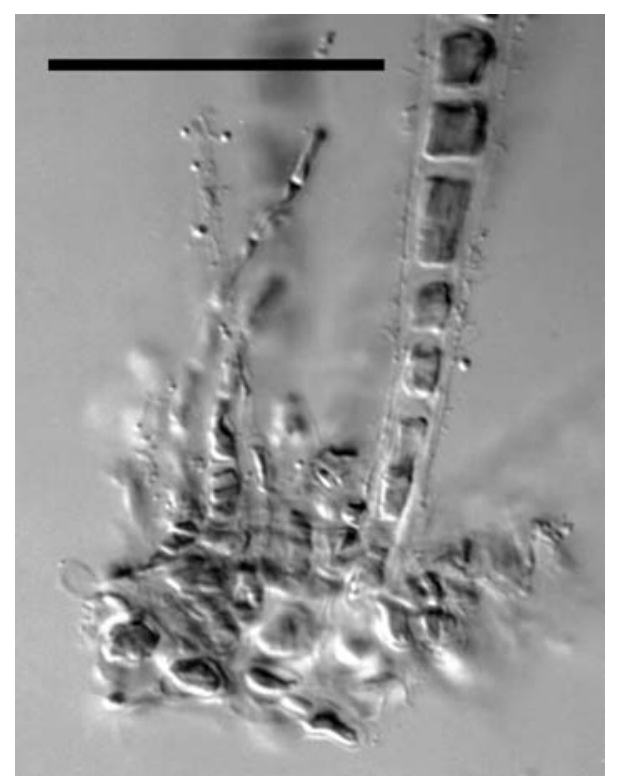

Figure 3 Porphyrostromium ciliare: multicellular base. $\mathrm{Bar}=50 \mu \mathrm{m}$ 
Wurdemanniaceae: Wurdemannia miniata (Sprengel) Feldmann et Hamel Described and illustrated in Lawson and John (1987), p. 181, plate 22, figures 4, 5.

Thalli comprised both an erect and prostrate, entangled wiry and irregularly branched component with multiaxial apices; branches were spine-like and pointed. The thallus grew to $8 \mathrm{~mm}$ tall. Thalli tetrasporic; tetrasporangial sori formed at branch tips with zonately divided sporangia (Figure 4). Wurdemannia miniata grew among an algal turf at mid to lower shore levels.

An amphi-Atlantic species that occurs widely in the tropical and warm temperate regions (Taylor 1960, Lawson and John 1987).

Specimen examined: Pico, Cais de Pico, 21.07.1989, BM000700560 (BM).

Halymeniales, Halymeniaceae: Cryptonemia seminervis (C. Agardh) J. Agardh Described and illustrated in Irvine and Farnham (1983), p. 20, figure 5 A-C.

A single large thallus $125 \mathrm{~mm}$ tall and $120 \mathrm{~mm}$ wide was found that comprised a divided frond with a distinct basal nerve and stipe that arose from a discoid holdfast. The thallus was multiaxial with medullary filaments and stellate cells surrounded by a cortex of 1-2 layers of small cells; larger cells separated the cortex from the medulla. The thallus was overgrown by algal and animal epiphytes. Cryptonemia seminervis grew attached to rock at $2 \mathrm{~m}$ depth in a rock-pool.

Cryptonemia seminervis occurs widely in the temperate northeastern Atlantic Ocean from the Channel Isles to Morocco (Irvine and Farnham 1983) and the Canary Islands (Haroun et al. 2002).

Specimen examined: São Miguel, Mosteiros, 15.11.2001, SMG-01-82b (UA).

Ceramiales, Delesseriaceae: Erythroglossum laciniatum (Lightfoot) Maggs et Hommersand Described and illustrated in Maggs and Hommersand (1993), p. 219, figure 69.

Azorean individuals formed small prostrate or erect membranous thalli that grew to $15 \mathrm{~mm}$ long and $3 \mathrm{~mm}$ wide. Thalli were pinkish-red, one to three-layered, divided but variable in shape, with macroscopic veins near the base and microscopic veins distally; occasional marginal teeth or triangular proliferations were present. Tetrasporangial sori occurred either side of a main vein. Thalli grew occasionally among Cladophora prolifera (Roth) Kützing and sponges in a shaded pool at low eulittoral levels.

Erythroglossum laciniatum occurs in the northeastern Atlantic Ocean from Great Britain and Ireland to Portugal, and also the Mediterranean Sea (Maggs and Hommersand 1993).

Specimen examined: São Miguel, Capelas, 21.03.2002, SMG-02-117 (UA).

Rhodomelaceae: Bostrychia scorpioides (Hudson) Montagne ex Kützing Described and illustrated in Maggs and Hommersand (1993), p. 287, figure 88.

Azorean thalli formed small brownish-purple filamentous tufts $10-40 \mathrm{~mm}$ high, attached to rock by haptera developed on prostrate parts of axes. Thalli were of

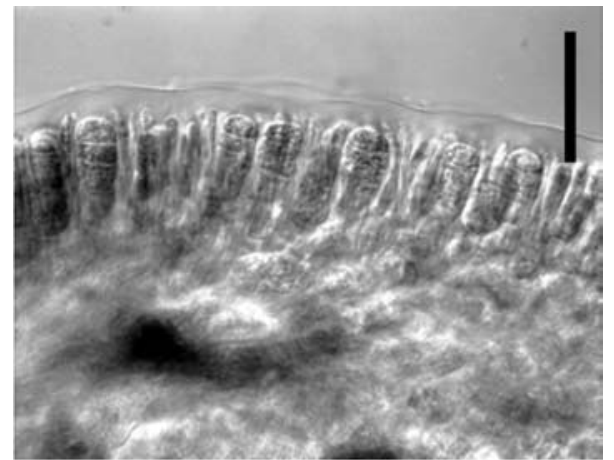

Figure 4 Wurdemannia miniata: tetrasporangial sorus with zonate tetraspores. Bar $=50 \mu \mathrm{m}$.

branched, terete filaments; branches alternately or distichously arranged, apices inrolled to the lower side of the thallus. Main axes were to $117 \mu \mathrm{m}$ in diameter. Filaments comprised 2 rings of periaxial cells surrounding each axial cell and an external cortication. Haptera were formed from fused multicellular rhizoidal filaments. Fertile thalli have not been recorded in the Azores. The species grew on high eulittoral rocks as sporadic tufts in early spring.

Bostrychia scorpioides occurs widely in the northeastern Atlantic Ocean (British Isles to Morocco), the Mediterranean Sea and elsewhere (Maggs and Hommersand 1993).

Specimen examined: São Miguel, Lagoa, 18.03.2002, SMG-02-47 (UA).

Rhodomelaceae: Ctenosiphonia hypnoides (Welwitsch ex J. Agardh) Falkenberg Described and illustrated in Falkenberg (1901), p. 485, plate 9, figures 11-15, and Ardré (1970), plate 30.

Thalli formed branched filamentous tufts with prostrate and dorsiventrally arranged erect axes. The axes were recurved towards the substratum, polysiphonous with 16-18 periaxial cells, and the main axis measured

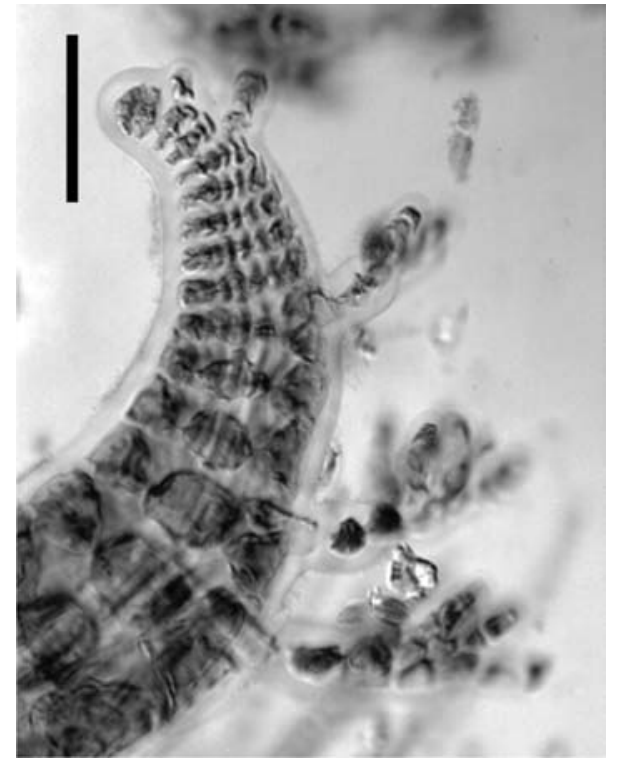

Figure 5 Ctenosiphonia hypnoides: trichoblasts linearly arranged on outer side of recurved axis. Bar $=50 \mu \mathrm{m}$. 
$154 \mu \mathrm{m}$ in diameter. Branches arose endogenously from the upper surface of an axis; branched trichoblasts occurred linearly on the outer (convex) side of recurved axes (Figure 5). Ctenosiphonia hypnoides grew on mid and low eulittoral rocks, often among other algae.

The species occurs in the northeastern Atlantic Ocean from France to the Canary Islands (South and Tittley 1986, Haroun et al. 2002).

Specimens observed: São Miguel, Lagoa, 18.03.2002, SMG-02-59 (UA); São Miguel, Capelas, 21.03.2002, SMG-02-124 (UA); São Miguel, Caloura, 25.02.2003, SMG-03-19 (UA).

\section{Confirmed old records}

Chlorophycota, Chlorophyceae, Codiolales, Ulotrichales: Ulothrix flacca (Dillwyn) Thuret Described and illustrated in Lokhorst (1978), pp. 207-212, figures $6-10$.

Occasional filaments occurred among Bangia, Blidingia and Porphyra species on rocks at high eulittoral levels in early spring.

Ulothrix flacca occurs widely in the North Atlantic Ocean (east and west coasts) and the Canary Islands (Afonso-Carillo and Sansón 1999).

Specimen examined: São Miguel, Lagoa, 18.03.2002, SMG-02-50 (UA). This confirms the older record of Schmidt (1931).

Cladophorales, Boodleaceae: Phyllodictyon anastomosans (Harvey) Kraft et Wynne Described and illustrated by Kraft and Wynne (1996), p. 131, figures 16-25.

Phyllodictyon anastomosans grew as diminutive thalli with poorly formed blades comprising a network of branched filaments arising from a unicellular stipe. The Flores specimen was $15 \mathrm{~mm}$ high while that from Formigues was only $5 \mathrm{~mm}$ tall. The species occurred rarely, attached to rock in deep water at 29-32 $\mathrm{m}$ on Flores and $45 \mathrm{~m}$ on Formigues.

This species occurs widely in the tropical Atlantic Ocean (Taylor 1960, Haroun et al. 2002).

Specimens examined: Formigues, 07.06.1990, For-90119 (UA); East of Flores, CANCAP expedition, L997.063 076 (L). These confirm the earlier record of Ardré et al. (1973), for which a specimen was not available for study.

Chromophycota, Phaeophyceae, Ectocarpales, Ectocarpaceae: Ectocarpus siliculosus (Dillwyn) Lyngbye Described and illustrated in Russell (1966), pp. 275-279, figures 3, 4.

Similar to Ectocarpus fasciculatus but differs in the narrow and elongate shape of the plurilocular sporangia (to $92 \mu \mathrm{m}$ long and $20 \mu \mathrm{m}$ wide) and with terminal pseudohairs. E. siliculosus grew on rocks and in pools at low eulittoral levels.

Ectocarpus siliculosus is an amphi-Atlantic species that extends south to the Canary Islands (South and Tittley 1986, Haroun et al. 2002).

Specimens examined: São Miguel, São Vicente, 01.05.1994, SMG-94-387 (UA); São Miguel, Caloura, 24.07.1997, SMG-97-342 (UA); São Miguel, Mosteiros, 30.04.1998, SMG-98-231 (UA); São Miguel, Mosteiros,
07.05.1998, SMG-98-251 (UA); São Miguel, Capelas, 21.03.2002, SMG-02-125 (UA). These confirm the older records of Schmidt (1931).

Rhodophycota, Bangiophycideae, Bangiales, Bangiaceae: Bangia atropurpurea (Roth) C. Agardh Described and illustrated in Brodie and Irvine (2003), p. 92, figure 29.

This alga occurred as unbranched filaments or filiform strands to $70 \mathrm{~mm}$ long. Thalli were uniseriate basally, parenchymatous above. Thalli grew closely adherent to rock at high eulittoral levels together with Ulothrix and Porphyra sp. in late winter and early spring.

Bangia atropurpurea is an amphi-Atlantic species that occurs south to tropical Africa (Brodie and Irvine 2003).

Specimens examined: São Miguel, Lagoa, 20.03.1990, SMG-90-40 (UA); São Miguel, Caloura, 23.02.1999, SMG-99-440 (UA); São Miguel, Lagoa, 21.02.2000, SMG-00-156 (UA); São Miguel, São Vicente, 20.03.2002, SMG-02-65 (UA); Pico, Cais de Madalena, 20.01.1972, B. Gonçalves, 454, BM000767052 (BM); Faial, Veradouro, 12.04.1967, B. Gonçalves, 190, BM000767022 (BM); Corvo, Porto Novo, 20.06.1972, B. Gonçalves, 523, BM000767034 (BM). These confirm the older records of Schmidt (1931).

Florideophycideae, Bonnemaisoniales, Bonnemaisoniaceae: Asparagopsis taxiformis (Delile) Trevisan Described and illustrated in Taylor (1960), p. 348, plate 71, figure 4.

Erect gametophytic thalli, pyramidal in form, brownishred in colour, grew to $300 \mathrm{~mm}$ tall and arose from basal matted stoloniferous growths. The main axis was distinct and naked below and bore many alternately arranged lateral branches also naked below; further orders of branches were pinnately arranged. Only male gametangia have been found. Thalli grew at sublittoral levels, 2-15 m depth.

Asparagopsis taxiformis occurs commonly and widely in the warmer southern parts of the North Atlantic Ocean to Bermuda (gametophyte thalli; Schneider and Searles 1991), North Carolina (tetrasporophyte thalli; Schneider and Searles 1991), the Canary Islands (Haroun et al. 2002) and Mediterranean Sea (gametophyte thalli), and possibly as far north as France (South and Tittley 1986).

Specimens examined: São Miguel, Ponta DelgadaPesqueiro, 23.09.1993, SMG-93-37 (UA), 25.09.1993, SMG-93-70 (UA), 28.08.1993, SMG-93-121 (UA); São Miguel, Ponta Delgada-Marina, 18.03.1995, SMG-95-05 (UA); São Miguel, São Vicente, 23.07.1996, SMG-96-350 (UA); São Miguel, Baia de Belém, 12.04.2002, SMG-02139 (UA); São Miguel, São Rocque, 03.05.2002, SMG02-189 (male) (UA). These confirm the older records of Schmidt (1931).

\section{Discussion and conclusion}

Of the algae reported here six (Bangia atropurpurea, Ectocarpus fasciculatus, E. siliculosus, Porphyrostromium ciliare, Ulothrix flacca and Ulvaria oxysperma) are widespread amphi-Atlantic species that extend in distri- 
butional range south at least to the Canary Islands. Cryptonemia seminervis, Ctenosiphonia hypnoides and Phyllophora sicula are known only from the northeastern Atlantic Ocean and also extend south to the Canary Islands. The new records from the Azores fill gaps in their overall distributions. The Azores archipelago is the western limit of distribution in the North Atlantic Ocean of Bostrychia scorpioides, Bryopsis cupressina, Cryptonemia seminervis, Erythroglossum laciniatum and Haliptilon squamatum, and the southern limit of distribution of Codium fragile ssp. atlanticum and E. laciniatum. The presence of the tropical species, Asparagopsis taxiformis, Phyllodictyon anastomosans, Valonia macrophysa and Wurdemannia miniata indicates the warm-temperate nature of the algal flora of the Azores. Most of these species reach their northern distributional limit there.

Erect terete species of Codium [C. decorticatum (Woodward) Howe, C. fragile, C. tomentosum Stackhouse, C. vermilara (Olivi) Chiaje] have been recorded previously from the Azores. Codium fragile has been found recently on the islands of São Miguel (Neto 1997) and Flores (Tittley et al. 1998) but without subspecific identification. This study revealed specimens to have mucron lengths characteristic of $C$. fragile ssp. atlanticum and $C$. fragile ssp. tomentosoides. Both subspecies of $C$. fragile are introductions to the North Atlantic Ocean and, despite the isolation of the Azores, these algae along with other non-native species have established successful populations widely in the archipelago. It is unclear whether dispersal was natural or involved an anthropogenic vector.

Asparagopsis taxiformis is an uncommon component of the marine algal flora of the Azores. Dixon and Irvine (1977) and Lawson and John (1987) have questioned the separateness of $A$. armata and $A$. taxiformis. The principal differences between the gametophyte thalli are that $A$. armata Harvey has spiny branchlets, $A$. taxiformis is more densely branched, and $A$. armata is a paler shade of red. The tetrasporophyte stages are indistinguishable. A. armata is a non-native species first recorded in the North Atlantic Ocean in northern France in 1922 (Farnham 1998). It is widespread on rocky shores in the Azores where it forms a dense belt in the summer period at sublittoral fringe and shallow sublittoral levels; the belt dies back during winter. Lawson and John (1987) described a dense belt of $A$. taxiformis in tropical West Africa and both species occur in the Canary Islands. Schmidt (1931) recorded $A$. taxifomis (as A. delilei Montagne) as widespread in the Azores but there are no confirming specimens. The earliest specimens of Asparagopsis from the Azores in BM were of $A$. armata (BM000718863, BM000767046) collected in 1952 coincident with a period of time when $A$. armata was actively spreading around Great Britain and Ireland (Irvine et al. 1975). These specimens and others collected in 1959 (BM000718226, BM000718233) were misidentified as $A$. taxiformis. Asparagopsis armata may have displaced $A$. taxiformis in the Azores although recent observations at Lajes de Pico on Pico island suggest that locally the reverse is occurring.

Bostrychia scorpioides in northern Europe is often found as dense stands in saltmarsh, estuaries and other low salinity situations. It was recorded by Price et al. (1981) in southwestern England, occurring year round at upper eulittoral levels on hard rocky substrata in estuarine conditions ranging from reduced to almost full salinity. The Azores population also grew at upper eulittoral levels but in contrast to England, it was on the open coast, in fully marine conditions, and seasonal (winter to spring) in occurrence.

Schmidt (1931) previously recorded Ulothrix flacca, Ectocarpus siliculosus [as E. confervoides (Roth) Kjellman] and Bangia atropurpurea. Recent field studies have now provided supporting specimens and have revealed that all occur seasonally and sporadically.

Ulva (Enteromorpha) clathrata without spiny branches (see Blomster et al. 1999) has been found only once in the Azores (Faial, Laginha, 28.08.1971, B. Gonçalves 371, BM000767003); the label with the specimen indicated that it grew in coastal saline ponds, an uncommon habitat on the Azores. The synonymous E. muscoides (Clemente y Rubio) Cremades [E. ramulosa (Smith) Hooker] with spiny branches has long been known on open shores. Recently, Blomster et al. (1999) showed by molecular studies that $E$. muscoides and $E$. clathrata are morphologically variable species that can be distinguished from other Ulva (Enteromorpha) species but not from each other. The form of Rhizoclonium tortuosum (Dillwyn) Kützing with rhizoidal outgrowths has not been reported in the Azores but the synonymous Chaetomorpha ligustica (Kützing) Kützing (without rhizoidal outgrowths) has been found on Faial [BM000766980, BM000766980 as C. capillaris (Kützing) Børgesen] and Pico (BM000766979, BM000766982, BM000766983 as C. capillaris).

The following misidentified species have been removed from the Azores marine flora (cf. Neto 1994): Ahnfeltia plicata (Hudson) Fries, Brongniartella byssoides (Goodenough et Woodward) F. Schmitz (see Parente and Neto 2000), Calliblepharis ciliata (Hudson) Kützing, Chondrus crispus Stackhouse, Cordylecladia erecta (Greville) J. Agardh, Dumontia contorta (S.G. Gmelin) Ruprecht, Fucus ceranoides Linnaeus, F. vesiculosus Linnaeus, Halichrysis depressa (C. Agardh) Schousboe, Lomentaria baileyana (Harvey) Farlow, Mastocarpus stellatus (Stackhouse) Guiry, Palmaria palmata (Linnaeus) Kuntze, Polysiphonia simpliciuscula P. Crouan et $\mathrm{H}$. Crouan and Spatoglossum schroederi (C. Agardh) Kützing. Many of these are species from the northern North Atlantic Ocean and their inclusion probably reflects a northern European influence on previous floristic research.

The occurrence of Fucus vesiculosus Linnaeus was based on nomenclatural confusion and misidentification with F. spiralis Linnaeus. Drouet (1866) cited "var. $\gamma$ spiralis Ag." (i.e., F. spiralis) under F. vesiculosus; Trelease (1897) did the same (as F. vesiculosus var. spiralis) but noted that specimens were attached, $50 \mathrm{~mm}$ long, without bladders, and were the same as $F$. sherardii auct. ( $=F$. spiralis). A specimen in BM from São Miguel collected in the 1840s and labelled F. vesiculosus (BM000642639) had no bladders but sterile margins to the receptacles, a distinguishing feature of $F$. spiralis. A specimen in BM from Madeira (BM000642640) labelled $F$. vesiculosus was similarly misidentified, and as F. spiralis, is the first con- 
firmed record of the genus for that archipelago (cf. Neto et al. 2001). Fucus vesiculosus is amphi-Atlantic (South and Tittley 1986) and reaches its southern limit of distribution in the Canary Islands. Davy de Virville and Denizot (1958) suggested that the occurrence of $F$. vesiculosus in the Canaries was a recent southward extension in range. Tittley et al. (2005) drew attention to the spasmodic occurrence of Fucus serratus Linnaeus over the past century on the Faroes in the northern North Atlantic Ocean. In America F. vesiculosus extends further south (North Carolina; Schneider and Searles 1991) than F. spiralis (New York; Taylor 1957). The Azores archipelago lies within the potential geographical range of $F$. vesiculosus but has not been colonised by it. Also removed from the flora is the rafting species Sargassum natans (Linnaeus) Gaillon that probably arrives on the Azores via the North Atlantic Current from populations in the Caribbean Sea (Littler et al. 1989).

The new algal records for the Azores itemised here and recently elsewhere are mostly of species known from other locations in the North Atlantic Ocean, particularly warm water areas. Despite the isolation of the archipelago from Europe, Africa and America, endemism in the Azores is low, and there is not a locally distinct flora. Tittley (2003) noted the marine algal flora of the warmtemperate Azores to be considerably species-poorer than that of the subtropical Canary Islands (628 species recorded). It is similar to that of the Madeiran archipelago (359 recorded; Neto et al. 2001) but with only 161 (45\%) shared species (Tittley 2003). It has a species-richer flora than most other floras of the cooler regions of the North Atlantic Ocean except for Atlantic France, Great Britain, Ireland and Spain. Other island groups such as the Faroes and Shetlands have fewer than 300 species (Tittley et al. in press) while those of the warm water South Atlantic (e.g., Ascension, St. Helena) are poorer in species (Tittley 2003). Recent investigation has almost doubled the number of species known in the Azores. South and Tittley (1986) listed 189 species and Tittley et al. (2001) noted an increased total of 360 . The present total (with the exclusions above) stands at 368 (56 Chlorophyceae, 75 Phaeophyceae, 237 Rhodophyceae) and further additions are under investigation. In keeping with the warmer-water algal floras of the North Atlantic Ocean the Azores flora has a larger proportion of Rhodophyceae (Tittley 2003). The biogeographically variable nature of these records corresponds to the overall mixed nature of the marine algal flora of the Azores with elements shared with Macaronesia, the Mediterranean Sea, Atlantic Europe, and the subtropical and tropical Atlantic America. The discovery of new algal records in the Azores demonstrates the need for continuing taxonomic and floristic study in the North Atlantic Ocean despite its being relatively well known compared with other oceans.

\section{Acknowledgements}

The Natural History Museum, London is acknowledged for financial support for studies in the field. This work was also partially funded by CIRN-Centro de Investigação de Recursos Naturais, Fundação para a Ciência e a Tecnologia. Sandra Monteiro, Manuela Parente and Francisco Wallenstein (UA) are thanked for their help in the field and laboratory. Peter York (BM) is thanked for the preparation of photomicrographs, Dr D.M. John (BM) for comments on nomenclature, and Dr J. Brodie (BM) for confirming Porphyrosiphon and Bangia.

\section{References}

Afonso-Carillo, J. and M. Sansón. 1999. Algas, hongos, y fanerógamas marinas de las Islas Canarias Clave analitica. Universidad de la Laguna, La Laguna. pp. 254.

Ardré, F. 1970. Contribution à l'étude des algues marines du Portugal I. La Flore. Port. Act. Biol. B. 10: 137-155.

Ardré, F., C.-F. Boudouresque and J. Cabioch 1973. Note pré liminaire sur la mission "BiAçores" du N.O. Jean Charcot (Algologie). Bull. Soc. Phyc. France 19: 178-182.

Bliding, C. 1968. A critical survey of European taxa in Ulvales, II Ulva, Ulvaria, Monostroma, Kornmannia. Bot. Notiser 121: 535-629.

Blomster, J., C.A. Maggs and M. Stanhope 1999. Extensive intraspecific and morphological variation in Enteromorpha muscoides (Chlorophyta) revealed by molecular analysis. J. Phycol. 35: 575-586.

Brodie J.A. and L.M. Irvine 2003. Seaweeds of the British Isles. Volume 1: Rhodophyta, Part 3B, Bangiophycidae. Intercept, Andover. pp. xiii, [1], 167.

Davy de Virville, A. and M. Denizot 1958. Sur l'extension, vers le Sud, de l'aire de répartition du Fucus vesiculosus. C. $r$. Hebd. Séanc. Acad. Sci., Paris, 247: 323-325.

Dixon, P.S. and L.M. Irvine. 1977. Seaweeds of the British Isles. Volume 1: Rhodophyta, Part 1, Introduction, Nemaliales, Gigartinales. British Museum (Natural History), London. pp. xi, 252.

Drouet, H. 1866. Catalogue de la Flore des lles Açores précédé de l'itinéraire d'un voyage dans cet archipel. Mem. Soc. Acad. De l'Aube 30: 1-153.

Falkenberg, P. 1901. Die Rhodomelaceen des Golfes von Neapel und der angrenzenden Meeresabschnitte. Fauna und Flora des Golfes von Neapel 26. pp. xvi, 754.

Farnham, W.F. 1998. Introduced species in the English Channel and North Sea. In: (G.W. Scott and I. Tittley, eds) Changes in the marine flora of the North Sea. Centre for Environmental Research into Coastal Issues, Scarborough. pp. 99-117.

Haroun, R.J.M., C. Gil-Rodríguez, J. Díaz de Castro and W.F. Prud'homme van Reine. 2002. A check-list of the marine plants from the Canary Islands (central eastern Atlantic Ocean). Bot. Mar. 45: 139-169.

Harper, J.T. and D.J. Garbary. 1997. Marine algae of northern Sénégal: the flora and its biogeography. Bot. Mar. 40: 129-138.

Irvine, L.M. and Y.M. Chamberlain. 1994. Seaweeds of the British Isles. Volume 1: Rhodophyta, Part 2B, Corallinales, Hildenbrandiales. HMSO, London. pp. vii, 276.

Irvine, L.M. and W.F. Farnham. 1983. Halymeniaceae. In: (L.M. Irvine, ed.) Seaweeds of the British Isles. Volume 1: Rhodophyta, Part 2A, Cryptonemiales (sensu stricto), Palmariales, Rhodymeniales. HMSO, London. pp. 17-29.

Irvine, D.E.G., M.D. Guiry, I. Tittley and G. Russell. 1975. New and interesting marine algae from the Shetland Islands. $\mathrm{Br}$. Phycol. J. 10: 57-71.

Kraft, G.T. and M.J. Wynne 1996. Delineation of the genera Struvea Sonder and Phyllodictyon J.E. Gray (Cladophorales, Chlorophyta). Phycological Res. 44: 129-142.

Lamouroux, J.V. 1809. Observations sur la physiologie des algues marines, et description de cinq nouveaux genres de cette famille. Nouv. Bull. Sci. Soc. Philomat. Paris 3: 181-188.

Lawson, G.W. and D.M. John. 1987. The marine algae of the coastal environment of tropical West Africa. 2nd edition. Beih. Nov. Hedw. 93. J. Cramer, Berlin. pp. vi, 415. 
Littler D.S., M.M. Littler, K.E. Bucher and J.N. Norris. 1989. Marine plants of the Caribbean A field guide from Florida to Brazil. Airlife Publishing Ltd., Shrewsbury. pp. vii, 263.

Lokhorst, G.M. 1978. Taxonomic studies on the marine and brackish-water species of Ulothrix (Ulotrichales, Chlorophyceae) in western Europe. Blumea 24: 191-299.

Maggs, C.A. and M.A. Hommersand. 1993. Seaweeds of the British Isles. Volume 1: Rhodophyta, Part 3A Ceramiales. HMSO, London. pp. xv, 444

Neto, A.I. 1994. Checklist of the benthic marine algae of the Azores. Arquipélago, Life and Marine Sciences, 12A: 15-24.

Neto, A.I. 1997. Studies on algal communities of São Miguel, Azores. Tese de doutoramento, Universidade dos Açores, Ponta Delgada.

Neto, A.I. 2001. Macroalgal species diversity and biomass of subtidal communities of São Miguel (Azores). Helg. Mar. Res. 55: 101-111.

Neto, A.I., D.C. Cravo and R.T. Haroun. 2001. Checklist of the benthic marine plants of the Madeiran Archipelago. Bot. Mar. 44: 391-414.

Neto, A.I., M.R. Terra and R.J. Haroun. 2002. New foliose and gelatinous red macroalgae (Rhodophycota) from the Azores: morphological and geographical observations. Aquat. Bot. 72: 1-11.

Parente, M.I. and Neto A.I. 2000. New records of benthic marine red algae (Ceramiales: Rhodophyta) from the Azores. Arquipélago, Life and Marine Sciences, Suppl. 2A: 53-61.

Parente, M.I., R.L. Fletcher and A.I. Neto. 2000. New records of brown algae (Phaeophyta) from the Azores. Hydrobiologia 440: 153-157.

Price, J.H., C.E.L. Hepton and S.I. Honey. 1981. The inshore benthic biota of the Lizard Peninsula, south west Cornwall II. The marine algae: Rhodophyta; Discussion. Cornish Stud. 8: 5-36.

Price, J.H., D.M. John and G.W. Lawson. 1992. Seaweeds of the western coast of tropical Africa and adjacent islands: a critical assessment. IV. Rhodophyta (Florideae) 3. Genera HK. Bull. Br. mus. Nat. Hist. (Bot.) 22: 123-146.
Russell, G. 1966. The genus Ectocarpus in Britain I. The attached forms. J. Mar. Biol. Ass. U.K. 46: 267-294.

Schmidt, O.C. 1931. Die marine Vegetation der Azoren in ihren Grundzügen dargestellt. Bibliotheca Botanica 102. E. Schweizerbartsche Verlagsbuchhandlung, Stuttgart. pp. viii, 116.

Schneider C.W. and R.B. Searles. 1991. Seaweeds of the southeastern United States Cape Hatteras to Cape Canaveral. Duke University Press, Durham and London. pp. xiv, 553.

Silva, P.C. 1955. The dichotomous species of Codium in Britain. J. Mar. Biol. Ass. U.K. 34: 565-577.

South, G.R. and I. Tittley. 1986. A checklist and distributional index of the benthic marine algae of the North Atlantic Ocean. Huntsman Marine Laboratory and British Museum (Natural History), St. Andrews and London. pp. 78.

Taylor, W.R. 1957. Marine algae of the northeastern coast of North America. The University of Michigan Press, Ann Arbor. pp. viii, 509.

Taylor, W.R. 1960. Marine algae of the eastern tropical and subtropical coasts of the Americas. University of Michigan Press, Ann Arbor. pp. x, 870

Tittley, I. 2003. Seaweed diversity in the North Atlantic Ocean. Arquipélago, Life and Marine Sciences, 19A: 13-25.

Tittley, I., A.I. Neto and W.F. Farnham. 1998. Marine algae of the island of Flores, Azores: ecology and floristics. Bol. Mus. Mun. Funchal, Suppl. 5: 463- 479.

Tittley, I., A.I. Neto, W.F. Farnham and M.I. Parente. 2001. Additions to the marine algal (seaweed) flora of the Azores. Bot. Mar. 44: 215-220.

Tittley, I., R. Nielsen and K. Gunnarson. 2005. Relationships of algal floras in North Atlantic islands (Iceland, Faroe, Shetland, Orkney). Frodskapparit Biofar Proceedings 2005: 1-20.

Trelease, W. 1897. Botanical observations on the Azores. Ann. Rep. Michigan Bot. Garden 8: 77-220.

Received 12 November, 2004; accepted 12 April, 2005 